\title{
ADDITIONS TO THE LIST OF CANADIAN COLEOPTERA.
}

BY ALVA H. KILMAN, RIDGEWAY, ONT.

(Continued from page IIO.)

3443-Trogoderma tarsale Melsh. Not rare.

3683-Carpophilus antiquns Melsh. Rare; under bark of dead maple and beech.

3686-Colastus maculatus Er. Rare; took three or four from the stump of a maple tree, cut while the sap was running.

37 I 2-Eupurcea peltoides Horn.

3753 - Cryptarcha strigata Fab.

3823 -Corticaria pumila Lec.

$387 \mathrm{I}-$ Bactridium striolatum Reit.

By placing chips on the top of fresh-cut stumps of maple, uak and other trees, and turning them from time to time, these lastnamed species are found. Attracted by the flowing sap, they hide under the chips and may be taken along with the more common species of Nitidulida, Trogositida, etc., in considerable numbers.

3987-Ptilodactyla angustata Horn. Swept from weeds. June. Not common.

3992-Eucinetus moxio Lec. Swept from bushes. Muskoka. August. 4015-*Cyphon collaris Guér. Rare; beaten from wild gooseberry. 4031-Dromceolus basalis Lec.

4038-Dromceolus striatus Lec.

These species, a few specimens of each, were got by beating. I have no record of the plant.

4097-Cardiophorus convexus Say. Not common on conifers. 42 I7-Elater pedalis Germ. Several taken in sweeping net. 4228-Elater socer Lec. Rare; found two under bark. 4229-Elater rubricollis Hbst. One by beating in July. - Elater? macilentus Rand. One taken on beech. June. 4290-*Agriotes oblongicollis Melsh.

4305-Melanotus longulus Lec.

4335-Melanotus tenax Say. Taken occasionally by beating shrubbery. June and July.

4439-Corymbites fulvipes Bland. Rare on beech and maple. June. 4475 - Corymbites fallax Say. Occasionally on thorn. 
4494-Corymbites aratus Lec. Two specimens on lake shore.

4542-Drapetes geminatus Say. I find these pretty little beetles in a certain locality each year on elder blossoms.

4666-Actenodes acornis Say. Rare; one specimen on oak.

4767-Rhyncheros sanguinipennis Say. Found one flying in a pine grove. Mr. Jas. White also got one on pine.

4820-Pyropyga decipiens Harr. Not rare; on beech and other foliage. June.

49I I-Podabrus corneus Lec. One specimen; no record.

5I77-Clerus nigriventris Lec. Quite abundant on pine brush. July and August.

5229-Laricobius Erichsoni Rosen. Takẻn on pine in May; quite common. This is the L. rubidus of the Toronto list and of Canadian collections.

5243-Ptinus bimaculatus Melsh. Three years ago I found one specimen crawling around in a cork-lined box used for duplicates. As I could not discover that my duplicates were infested, I did not overhaul the box. The following summer, June, 1887 , I found two or three specimens of this interesting beetle in the same box. Since then I have kept it as a breeding place for this species, and in May, $\mathbf{1} 888$, found several more specimens therein. I have no recollection of having ever placed in the box anything but Canadian beetles, and thus introduced it from abroad. The beetles submitted as food for the larvæ bear evidences of having been used as designed. Packard says that the commoner species, Ptinus fur Linn., is known to attack collections of insects.

$525 \mathrm{I}-$ Ernobius granulatus Lec.

5254-Ernobius luteipennis Lec. Both rare on pine. June.

5289 -Vrilletta convexa Lec. One specimen taken while beating. Mr. Ulke says :- "This is a California species; never before saw it east."

5339-Sinoxylon basilare Say. Rare.

5404-Ennearthron thoracicorne Zeigl.

5408-Odontosphindus denticollis Lec. Rare; swept from shrubbery. 5459a-Onthophagus Orpheus Panz. One specimen flying. August. 60 I I-..*Callidium cereum Newm. Two taken at Ridgeway on pine, one at Edmonton by Mr. White, and one at Hamilton by Mr. Johnston. 
6090-Phyton pallidum Say. I took a pair of these handsome little Longicorns on wilted leaves of red oak (Quercus rubra) July i 2 , I887. It is rare indeed.

6183a-Xylotrechus lumulatus Kirby. Not common on hickory, 6209-*Microclytus gazellula Hald. Several taken by Mr. Moffat at Hamilton. Three were taken here on hickory.

6609-Bassareus detritus Oliv. Several swept from foliage.

$667 \mathrm{I}-$ Pachybrachys trinotatus Melsh. Not common; taken by sweeping with net, but I cannot say upon what plant.

6945b-Oedionychis limbalis Melsh. Beaten from leaves of ash and linden. 7003-Systena blanda Melsh. Rarely found in moss. March.

7534-Hypophlous tenuis Lec. Not rare under bark of stumps. 7693-Canifa pusilla Hald. Quite common in fungi.

7698-Nothus varians Lec. Not common in crevices of bark on dead trees.

7840-Mordellistena convicta Lec. Found occasionally on thorn blossoms.

7900-Xylophilus nebulosus Lec. Taken while sweeping; rare. 7967 -Anthicus spretus Lec. Not rare; by sweeping in wet places. 8364-Apion erythrocerum Smith.

$837 \mathrm{I}$-Apion impunctistriatum Smith.

These were found in moss in spring.

8427-Phytonomus punctatus Fab. Common on lake shore and in meadows. June to September.

8429-Phytonomus setigerus Lec. A pair taken by Mr. Jas. White, of Edmonton, Ont., on the sand near some stream or pond.

8440-Listronotus sordidus Gyll. Rare ; on lake shore.

$85_{67}$-Onychylis nigrirostris Boh. Occasionally found on the shore.

8575-Endalus ovalis Lec. Swept in numbers from the grass growing on the margin of a pond in the woods. August.

8582 -Lissorhoptrus simplex Say. Common on the petals of the yellow pond-lily.

8607-*Otidocephalus Chevrolatii Horn. Not rare on leaves of elm, etc. $86 \mathrm{I}$-Magdalis perforata Horn.

8690-Thysanocnemis helvolus Lec. One specimen from foliage of hickory, July 26 ; this is a rare species.

8753 -Acamptus rigidus Lec. Not common on lake shore. 8786-Cryptorhynchus parochus Hbst. 
8788-Cryptorhynchus pumilus Boh.

8795-Cryptorhynchus fallax Lec.

These kinds I find occasionally on the bark of dead linden, etc.

8820 - * Acoptus suturalis Lec. Quite common on hickory. June and July. 8834 -Caliodes flavicaudis Boh. Rare; swept from smart weed ( $P$. persicaria).

8893 -Pseudobaris t-signum Boh. $907 \mathrm{I}$ - Pityophthorus cariniceps Lec.

9223-Brachytarsus alternatus Say.

These three species I have taken rarely while sweeping.

PREPARATORY STAGES OF EUPLEXIA LUCIPARA, LINN.

BY HARRISON G. DYAR, RHINEBECK, N. Y.

EGG.-Nearly spherical, flattened at the base, marked with about twenty-five longitudinal ribs and numerous transverse ridges, the former somewhat irregular and running to a depression on the summit; color whitish, with a circle around the middle and a spot on top of purplishbrown; these marks more or less confluent. Length about.5 m.m.

Newly-hatched LaRva,-Walks in the manner of a geometer, not using the central abdominal legs. It is of a whitish colour, with many black dots, from each of which arises a hair. Head, thoracic legs, and cervical spot, black. Duration of this stage about four days. When not feeding, the insect remains stretched out at full length on the back of a leaf.

After First Moult.--Semi-transparent, whitish, with fine black dots as in the previous stage, a transverse row to each segment. Head whitish, mouth-parts black. Duration of this stage four days.

After Second Moult.-Differs from the preceding only in size. Duration, five days.

After Third Moult.--Whitish, a blackish lateral band with traces of dorsal and sub dorsal lines on first three segments. Black piliferous dots. Duration, six days.

After Fourth Moult.--Much the same. The twelfth segment is somewhat thicker than the rest of the body. Semi-transparent, with the markings indistinct. Lateral line white, shaded with blackish above, the 


\section{$2 \mathrm{BHL}$ Biodiversity Heritage Library}

Kilman, A. 1889. "Additions to the list of Canadian Coleoptera." The Canadian entomologist 21, 134-137. https://doi.org/10.4039/Ent21134-7.

View This Item Online: https://www.biodiversitylibrary.org/item/22108

DOI: https://doi.org/10.4039/Ent21134-7

Permalink: https://www.biodiversitylibrary.org/partpdf/18066

\section{Holding Institution}

MBLWHOI Library

\section{Sponsored by}

MBLWHOI Library

\section{Copyright \& Reuse}

Copyright Status: NOT_IN_COPYRIGHT

This document was created from content at the Biodiversity Heritage Library, the world's largest open access digital library for biodiversity literature and archives. Visit BHL at https://www.biodiversitylibrary.org. 